Stuart Morley

is a partner and head of research at GVA Grimley, one of the UK's largest property advisers. The research team cover all aspects of the property market, with a particular emphasis on retail and leisure capacity and impact studies.

\section{Chris Evans}

is a chartered town planner specialising in tourism development and marketing. $\mathrm{He}$ is a director of The Tourism Company, one of the country's leading tourism, leisure and recreation consultancies. He is involved with tourism and leisure strategies for a variety of destinations in the UK and abroad, along with feasibility studies for new facilities and market research in the leisure sector.

\section{Keywords:}

investment, development, expenditure, demographic and socio-economic change

\section{The future for leisure property in the UK}

\author{
Stuart Morley and Chris Evans \\ Received (in revised form): 29th June, 2000
}

\begin{abstract}
Not so long ago, leisure was considered a Cinderella property sector. It was perceived to be driven by highly volatile discretionary spending, there were relatively few multiple occupiers (compared to, say, the retail sector), and what new development there was tended to be one-off single-use schemes often built for owner occupiers on a bespoke basis. As a sector it was almost completely ignored in property textbooks, and was considered very much to be a specialist part of the property profession.

This contrasts with the present situation as the sector is now increasingly viewed as a distinct, albeit varied, mainstream property sector in its own right. In the 1990 s the sector experienced strong expenditure growth and there is major representation by multiple occupiers in each sub-sector willing to take on long traditional institutional-type leases. This has stimulated institutional investment and helped cause a development boom of unprecedented magnitude, both in town centres to service eating and drinking (part of the move back to city-centre living) and out of centre in multi-use leisure parks (accessed by car), a form of development which hardly existed a decade ago.

This paper is an edited version of a document on the future of leisure produced for the RICS Research Foundation and published as part of 2020: Visions of the Future; it considers, briefly, the main drivers for change in the leisure sector and then considers the implications for the property market.
\end{abstract}

\section{DRIVERS FOR CHANGE}

\section{Expenditure}

The growth in incomes and the rising proportion of income and expenditure spent on leisure goods and services (as illustrated in Social Trends ${ }^{1}$ ) has driven the leisure sector since the end of the last war, a period which has seen incomes per head more than treble in real terms. ${ }^{2}$ Care needs to be taken with any statistics on leisure, however, as it is such a large and diverse sector and definitions relating to expenditure vary considerably. For example, some definitions of leisure include elements of tourism expenditure and also include home entertainment expenditure on leisure goods like televisions, videos, stereos, PCs etc. ${ }^{3}$

A distinction must therefore be made between leisure goods 
Distinction between leisure goods and leisure services

Leisure services share of total expenditure

\section{Volatile expenditure} growth (often classified as in-home leisure) the majority of which can really be classified as part of the retail sector, and leisure services (often referred to as out-of-home leisure). The latter includes catering (eating out etc), betting and gaming, football pools, bingo, lotteries etc and recreational and cultural services (eg cinemas, theatres, bowling, sports admissions etc). This is much closer to a definition of 'leisure' expenditure relating to the commercial property leisure sector but is still not ideal. In addition to the above, some definitions of out-of-home leisure include holidays.

The Office for National Statistics (ONS) publishes data on a quarterly basis on consumer expenditure covering many of the components of leisure services expenditure. ${ }^{4}$ These data show that, in constant price terms, leisure spending as a percentage of total consumer expenditure declined slightly from 13.3 per cent in 1963 to 11.3 per cent in 1982 , but subsequently increased to 13 per cent in 1998. Due to differing rates of inflation for leisure services and overall expenditure, expenditure on leisure services represents an increasing proportion of total expenditure in nominal terms, but a more static proportion in real terms, as Figure 1 shows. Leisure services expenditure, as defined by the Consumer Trends series, ${ }^{5}$ has shown growth of 2.5 per cent per annum in real terms over the last 25 years, the same growth rate as for total consumer expenditure and real disposable incomes. Business Strategies forecasts that leisure services expenditure will achieve a growth rate of 3.2 per cent per annum over the ten years from 1998 to $2008 .^{6}$

Although there is statistical evidence for the growth of leisure expenditure in broadly defined sub-sectors, there is limited evidence for the variety of individual leisure activities. The overall nature of consumption in the leisure industry is most unusual because it is made up of so many different activities and they have the potential for extraordinary rates of growth and decline; much more so than in most non-leisure industries. This is also true (to a lesser extent) of leisure services expenditure as a whole, which has been very

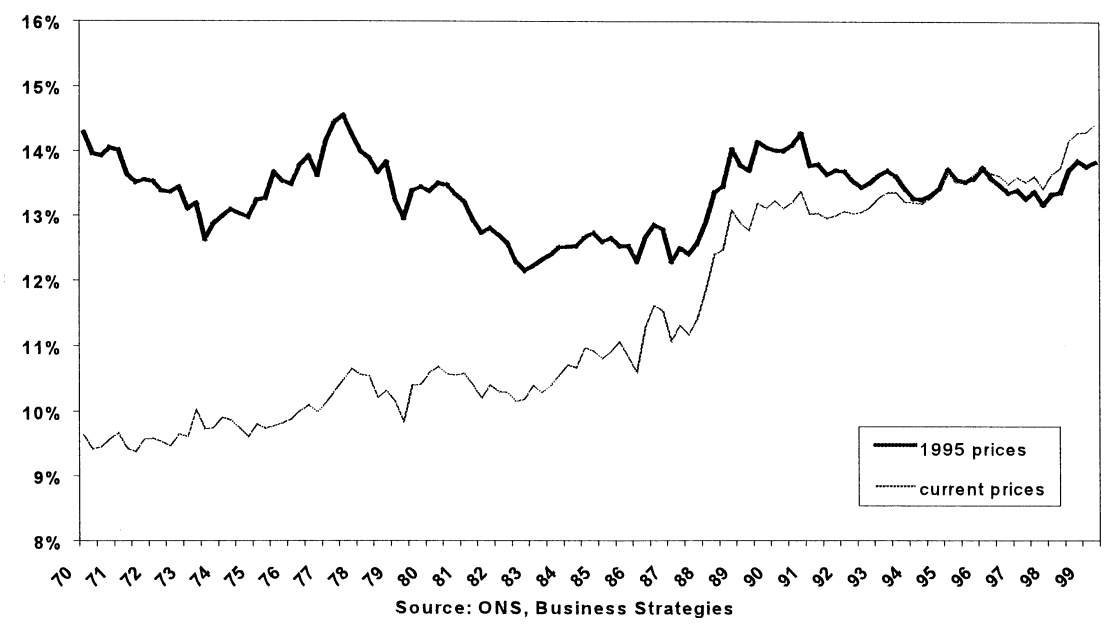

Figure 1: Leisure spending as percentage of total spending 


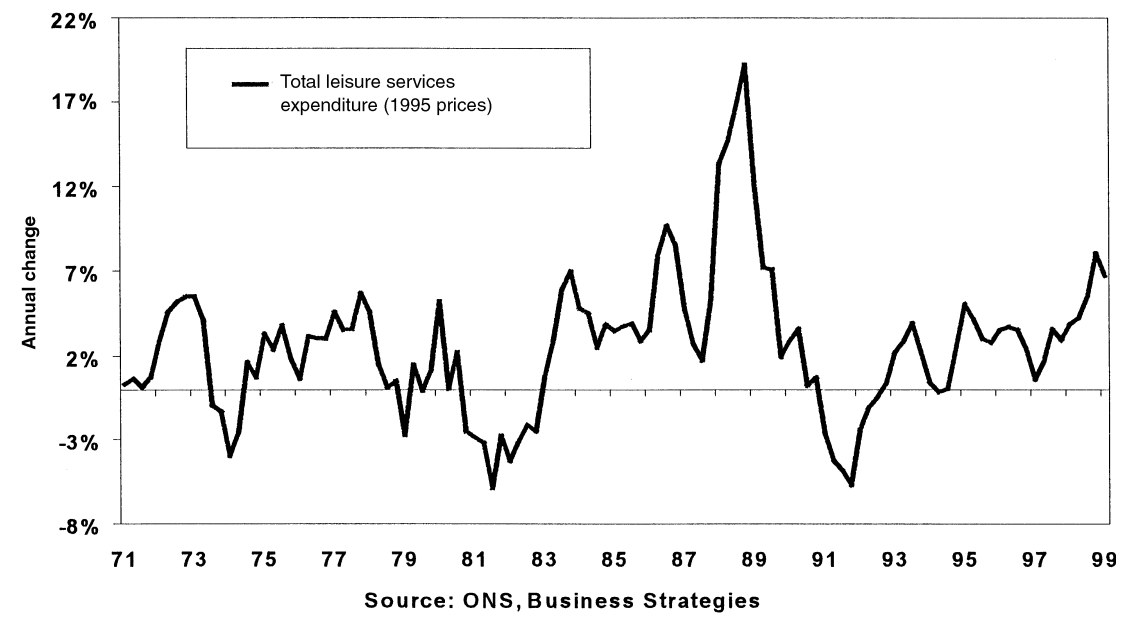

Figure 2: Total leisure services expenditure (1995 prices)

Dramatic decline and growth in cinema admissions

Emphasis on town centres and brownfield sites volatile, as Figure 2 illustrates. A classic example of volatility in expenditure is cinema admissions, declining from an immediate post-war peak of over 1.4 billion admissions to only 53 million admissions in 1984 and then rising to 128 million admissions in $1999 .^{7}$ Tenpin bowling and bingo have also shown significant fluctuations in popularity. While the growth in incomes and expenditure and demographic and socio-economic changes can explain part of this volatility, a key issue has been technological change - and the response from the property industry.

\section{Political policies}

A number of policies will affect the leisure sector over the next 20 years. The most important of these is environmental sustainability and accessibility, and the application of relevant principles through the planning system. This will mean a preference for town-centre locations ${ }^{8}$ and controls on parking, taxes on car use, higher petrol taxes etc. Another key issue is regeneration and the use of leisure development, particularly on brownfield sites (which may not be in town centres), to help finance urban regeneration. This could cause some conflict with the desire for sustainable development if these sites are not in or adjacent to town centres.

The attitude the government takes towards leisure in general will be important; whether they view it as an essential element in the quality of life of the population or whether it is seen as a luxury. Further regulation from the EU through directives on aspects such as the length of the working week and the minimum wage may also have a significant bearing on leisure development.

\section{Demographic changes}

A rapid increase is forecast (due to the post-war baby-boom cohort) in the number of people classed as 'older middle-aged' (5564). Most of these will reach retirement age over the next ten years 
Ageing population

Smaller households

Growing importance of women in the leisure market

Polarisation between cash rich/time-poor and time rich/cashpoor households or so, suggesting a significant growth in the number of retired people.

The baby-boom cohort of the 1960s will swell the proportion of the population seen as being in the 'family lifestage' (35-44), with this group moving onto the middle-age lifestage in the latter part of this decade. The decline in the under-16 age group is expected to continue for around another 20 years, with a fall of nearly 9 per cent predicted between 1996 and 2021. Clearly, different age groups have different leisure requirements and tastes, with young people, for example, particularly attracted to cinemas, bowling, nightclubs, bars etc.

The trend towards smaller households is also forecast to continue. By 2016, one-person households are expected to make up just over a third of all households, and there will be a continuing increase in the actual number of households in the UK; projections put the number of households in England and Wales at 24.6 million by 2016 , which is almost an 18 per cent increase on the number in 1996. ${ }^{9}$ One key issue emerging from this trend is the increased importance of third-place leisure destinations giving the opportunity to meet other people out of the home and place of work.

\section{Socio-economic changes}

Over the last 40 years the number of women in the workforce has increased significantly, from 35 per cent of employees in 1960 to 47 per cent in $1999 .{ }^{10}$ With a greater number of women entering the workforce and greater equality of opportunity, women have become and will continue to be an increasingly important sector of the leisure market. The increasingly important role of women in the workplace has had significant implications for the leisure industry, to which many leisure operators have responded (eg new-style pubs/ bars such as All Bar One, the Hogshead etc). Women are increasingly taking part in activities traditionally regarded as male dominated, such as travelling on business, visiting pubs, gyms and restaurants. Most leisure facilities are addressing security issues more closely in response to this trend. As leisure consumers, women will become more and more important and their buying power will increase, but responsibilities in the home as well as in the workplace may mean that women have less leisure time than men and fewer options to draw on.

Changing work structures and working hours and pressures at work, as well as the growth of women in the workforce, will all influence the amount of time available for leisure among different socio-economic groups. Further polarisation between cash-rich/ time-poor households and time-rich/cash-poor households seems likely, which will influence the relative value of time and money allocated for leisure activities. ${ }^{11}$

In Gratton's view ${ }^{12}$ the leisure industry does not appear to be suffering from the scarcity of leisure time as the length of the working week increases. Faced with less time, expenditure on 
In-home v out-ofhome leisure

Late 1990 leisure development boom leisure has increased, changing the type of leisure activities used.

\section{Technological changes}

It is difficult to foresee the scale or nature of technological change in the leisure sector over the next 20 years, other than to be sure it will have an impact. However, there are technological changes that are emerging now which might be extrapolated over a ten to 20year time frame. In the same way, 15-20 years ago the first multiplex cinema, the first PC and the first video had arrived so, in theory, their use could have been extrapolated and their effect on the leisure sector could possibly have been envisaged.

In-home entertainment accounts for the major share of leisure time, and technological trends could further increase this share. The Henley Centre, ${ }^{13}$ however, doubt that this will be significant; they argue that expenditure on new technological developments will take place largely at the expense of existing in-home rather than out-ofhome activities.

Hugely increased amounts of information will be available via the Internet, digital television and mobile 'phones. The ease of making reservations could also make a significant difference to outof-home leisure visits to sporting fixtures, cinemas, museums and art galleries, taking holidays etc.

From time to time, extravagant claims are made for new technology-based products, such as virtual reality centres and other simulators. Experience suggests that products based on technology for technology's sake are often short term or of specialist interest; there are few substitutes for leisure activities that cater for the ageold need for 'boy meets girl'. However, (multimedia) technology will add enormous value to traditional pursuits as it has done in the past, for example, via theme parks, the cinema, tenpin bowling and bingo.

\section{IMPLICATIONS FOR THE PROPERTY MARKET}

\section{Development}

The rise of the multiple leisure operator, the growth of leisure expenditure and the success in the 1980s and 1990s of out-of-town retail parks helped lead to the emergence of leisure parks in the 1990s. Other factors were also clearly of importance, such as planning policy, car ownership and land/building costs.

These factors, along with a general lowering of long-term interest rates and property investment yields in the mid/late 1990s, drove leisure yields downwards and capital values upwards: investors were prepared to accept lower yields initially, and hence pay higher capital values, when purchasing investments. Not surprisingly, the result of higher capital values and strong expenditure growth and occupier demand was a development boom in the latter half of the 1990s. Construction activity in the entertainment sector (as measured by the DETR's New Construction Orders data series published monthly ${ }^{14}$ ) 
Growing importance of the leisure sector

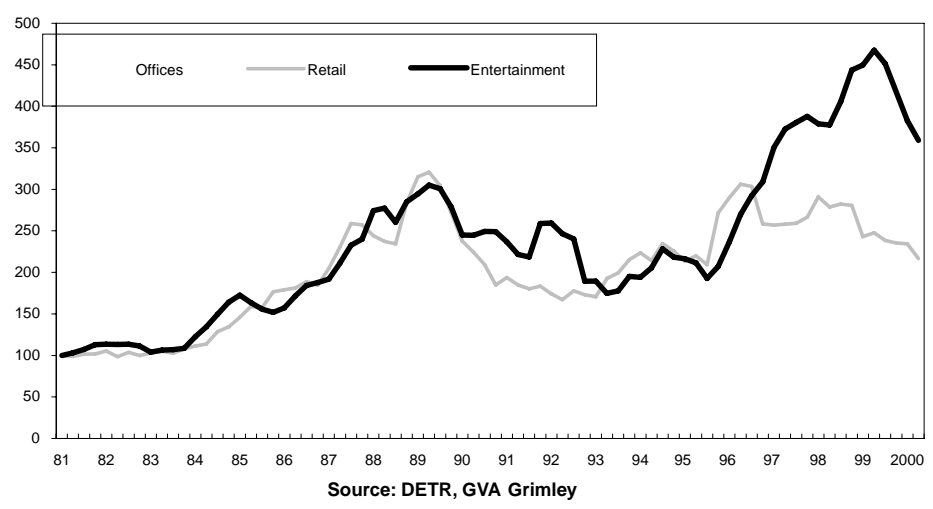

Figure 3: New construction orders (1995 prices), 12-month total

increased by over 100 per cent between 1995 and 1998. In constant price terms, the volume of new construction orders in 1998 was 50 per cent higher than in 1988/1989, at the peak of the late 1980s' boom. These rates of increase far surpassed those in other property sectors such as retail or offices, as Figure 3 shows.

This amount of development activity is exceptional, and a significant slowdown or major correction is likely. As Figure 3 shows, this appears to have already started. Nevertheless, the upward-sloping trend of construction activity is indicative of the growing importance of the leisure sector and the growth of leisure expenditure. It is, therefore, broadly indicative of the long-term increase in development activity that can be expected over the next 20 years, although not at the same rate that occurred in the latter half of the 1990s.

Much of the development activity in the 1990s was new development to cater for growing expenditure, new development concepts such as large individual leisure units (for multiple operators, whether it was multiplex cinemas or pubs, hotels etc) and larger composite schemes such as leisure parks. ${ }^{15}$ Over the next 20 years, as the leisure sector is very dynamic, there will no doubt continue to be a relatively high level of development activity, but the size and location of schemes is changing and will undoubtedly continue to change.

It is likely that over the next 20 years many first-generation leisure parks built in the 1990s will be redeveloped. 'Out-of-town' new development will be very difficult to achieve owing to planning constraints, which will increase the attraction, and the value, of existing leisure parks. This in turn should stimulate pressure for higher-density redevelopment to maximise land use and land values. However, landlords will be constrained by planning policies (favouring town centre and edge-of-centre locations), and by the length of occupier leases making vacant possession difficult and 
Integration of leisure and retailing

\section{Growing importance of leisure uses to making shopping centres more attractive}

expensive to achieve. Layout is likely to change, where permitted, with buildings being more integrated, creating better synergy between units.

A feature of some new leisure developments and redevelopments is the integration of leisure and retailing - the incorporation of retail uses into leisure schemes and leisure uses into retail schemes. This trend is likely to become more widespread and is well suited to town-centre locations, and there is evidence that developers and operators accept that town-centre locations can be successful. ${ }^{16}$ Leisure developments in the larger centres may well grow in size to increase their draw and could form a new wave of town-centre redevelopments, more reminiscent of the town-centre shopping developments of the 1970s. Lifestyle, leisure-oriented, impulse retailing will help create new destination centres to stimulate 'bricks-and-mortar' trade.

Many commentators ${ }^{17}$ suggest that the role of town centres will change. Greater competition from e-tailers will force them to become more like speciality shopping/leisure centres to attract customers. It is likely that much regular, routine shopping for the basic necessities will increasingly be done from home. To attract customers to town centres will mean that they must be attractive and offer something different, an experience which cannot be found at home. Leisure development could help achieve this and is likely to form a vital component of the 21 st-century town centre.

\section{Investment}

In 1991, a survey ${ }^{18}$ indicated that only 13 per cent of institutions held leisure properties in their portfolios, and two-thirds indicated that they would not consider investing in leisure property in the future. By the end of the 1990s, a significant change had occurred in the institutional outlook towards leisure property investment, due to the changes mentioned earlier. However, the market is still embryonic and there is, as yet, little established comparable evidence on rent reviews. But this was also true for retail warehouse parks and business parks a decade and a half ago, and gradually they emerged as established investment sectors in their own right. This suggests that the same will happen to leisure property investment. ${ }^{19}$

The success of Marylebone Warwick Balfour's leisure funds, enabling investors to take a share in a range of prime leisure investments without having to invest directly in individual schemes, which would entail greater risks and management problems, has stimulated interest in leisure property as an investment. This interest, in turn, should attract the larger investors to fund leisure developments and purchase leisure investments individually so that, in time, leisure will arguably become a fourth main commercial property investment sector alongside retail, office and industrial property.

The long-term growth potential of leisure expenditure and hence 


\section{Leisure property investment characteristics}

\section{Future importance of branding and active hands-on management}

rental values (subject to the level of floorspace supply), together with excellent covenant strength and long leases (longer than in other property sectors, where lease lengths are generally now significantly shorter than the once common $20 / 25$ years ${ }^{20}$ make leisure, potentially, an attractive property investment asset class. This attractiveness should lead to leisure property investment growing in importance, with institutional investment portfolios increasing in size and value. This growth, in turn, should enable its performance to be measured, once there are sufficient properties in institutional and property company portfolios and hence in the British Property Federation Investment Property Databank (IPD).

The growth of institutional leisure property investment may well coincide with a new attitude to property investment management, with investors forging closer links with tenants to improve overall performance. One factor that differentiates a leisure centre or leisure park from its retail equivalent is the degree of handson management require if full growth potential is to be achieved. ${ }^{21}$

In the future, there is some evidence to suggest that town centre schemes will become larger (for example, Printworks, Manchester, Broadway Plaza, Birmingham) and hands-on management will become commonplace, as it has for the better shopping centres. ${ }^{22}$ Eventually, this could mean short leases (to give greater management flexibility and avoid tenant mix being fixed for 25-plus years), turnover rents and out-sourcing day-to-day management to expert specialist companies. If that happens we could see centres being branded and actively marketed, and poor-performing tenants replaced, so that a close, mutually beneficial, partnership is forged between owners and operators. Ironically, one of the main advantages, from an investment point of view, of existing leisure parks is their long occupational leases to multiple operators. However, it is possible that in the future this could increasingly be seen as one of their disadvantages as it will hinder active management because of the lack of flexibility over tenant mix. The volatile nature of the leisure market as fashions change will arguably make it desirable for landlords to have the ability to vary the tenant mix at more frequent intervals than has been customary in the past.

\section{CONCLUSIONS}

Over the next two decades, leisure should increasingly become an important property sector. The location, size and nature of leisure developments are likely to change, and investment in leisure property should increase. Town planning will have to adjust to plan for the inevitable changes. These changes will require greater knowledge of the leisure sector and the ability to assess the capacity and impact of proposed developments. They will also necessitate a greater understanding of operators' businesses and needs, greater financial literacy in a low-inflation environment and a greater knowledge of technological change that will affect the nature and location of leisure activities. 


\section{References}

1. ONS (1997) Social Trends, Office for National Statistics; ONS (1998) Social Trends, Office for National Statistics.

2. ONS (1999) Economic Trends Annual Supplement, Office for National Statistics.

3. Social Trends, ref. 1 above.

4. ONS (1998) Consumer Trends, Office for National Statistics.

5. Ibid.

6. Business Strategies Ltd (1999) Consumer Market Outlook.

7. GB Cinema Exhibitors, June 2000 (and earlier issues), Office for National Statistics.

8. Planning Policy Guidance Note 13 (PPG13): Transport, March 1994 and Consultation Draft October 1999, DETR; Planning Policy Guidance Note 6 (PPG6): Town Centres and Retail Developments, revised June 1996, DETR.

9. DETR (1999) Projections of Households in England to 2021, DETR.

10. ONS (2000) Annual Abstract of Statistics, Office for National Statistics; HMSO (1973) Annual Abstract of Statistics, HMSO.

11. Gratton, C. (1996) Work, Leisure and the Quality of Life - A Global Perspective Leisure Industries Research Centre, Sheffield; Martin, W. and Mason, S. (1998) Transforming the Future - Rethinking Free Time and Work Leisure Consultants, Sudbury.

12. Gratton, ibid.

13. Henley Centre (1996) 'Leisure's Future', in Leisure Futures, Vol. 4.

14. DETR (annual) 'Orders for New Construction', published monthly.

15. Evans, C. and Morley, S. (2000) 'The Future of Leisure', in 2020 Visions of the Future, RICS Research Foundation.

16. LPAC and London Transport (1999) Leisure Development in London.

17. Jones Lang La Salle (2000) Retail 2010; Sparks, L. and Findlay, A. (2000) 'The Future of Shopping, in 2020 Visions of the Future, RICS Research Foundation.

18. Sayce, S. (1998) 'An Examination of the Suitability of Leisure Properties as an Institutional Investment Vehicle', unpublished PhD thesis, University of Reading.

19. DTZ Debenham Thorpe (1995) 'Invest at Leisure', special report.

20. British Property Federation Investment Property Databank (1999) Annual Lease Review, London.

21. Leadbetter, S. (1999) Interview with Simon Leadbetter of Marylebone, Warwick, Balfour.

22. Ibid. 